Prismatika: Jurnal Pendidikan dan Riset Matematika Vol. 3 No. 1 (2020)

p-ISSN: 2654-6140, e-ISSN: 2656-4181

http://ejurnal.budiutomomalang.ac.id/index.php/prismatika

\title{
MENINGKATKAN MOTIVASI BELAJAR SISWA MELALUI MEDIA KUBUS BERANAK DALAM PEMBELAJARAN MATEMATIKA
}

\author{
Dike Rinanda Irfi'ani' ${ }^{1}$, Wuli Oktiningrum ${ }^{2}$ \\ Universitas Islam Raden Rahmat Malang ${ }^{1,2}$ \\ dikerinanda2ipa@gmail.com ${ }^{1}$,wulie.okti@uniramalang.ac.id ${ }^{2}$
}

\begin{abstract}
Abstrak
Media pembelajaran pada materi volume bangun ruang kubus kurang termanfaatkan dalam pembelajaran matematika kelas 5 Sekolah Dasar. Penelitian ini bertujuan untuk meningkatkan motivasi belajar siswa pada materi volume bangun ruang kubus melalui media pembelajaran kubus beranak dalam pembelajaran matematika kelas 5 Sekolah Dasar. Prosedur penelitian ini menggunakan desain pengembangan model ADDIE yang terdiri dari Analisys, Design, Development, Implementation, Evaluation. Peningkatan motivasi belajar siswa dilihat dari perbandingan hasil motivasi belajar siswa sebelum dan sesudah menggunakan media kubus beranak berdasarkan angket. Hasil penelitian ini menunjukkan bahwa tingkat kevalidan media ini diperoleh berdasarkan penilaian ahli materi 81,6\% dengan kriteria kevalidan sangat valid, ahli media $72,5 \%$ dengan kriteria kevalidan valid, ahli rencana pelaksanaan pembelajaran 89,3\% dengan kriteria kevalidan sangat valid, ahli lembar kerja siswa 91,6\% dengan kriteria kevalidan sangat valid. Respon siswa terhadap media kubus beranak diperoleh nilai rata-rata $81,1 \%$ dengan kategori penilaian baik sekali, respon guru terhadap media kubus beranak diperoleh nilai $100 \%$ dengan kategori penilaian baik sekali. Berdasarkan data motivasi belajar siswa sebelum menggunakan media kubus beranak rata-rata 53,61 dengan kategori cukup menjadi 81,04 dengan kategori sangat tinggi meningkat setelah menggunakan media kubus beranak.
\end{abstract}

Kata kunci: media pembelajaran, kubus beranak, motivasi belajar siswa

\begin{abstract}
The lack of use of instructional media on the volume material for building cubic spaces in mathematics learning for grade 5 elementary schools. This study aimed to improve students' learning motivation on the volume material of cubes through learning media cubes beranak in mathematics learning in grade 5 elementary school. This research procedure used the ADDIE model development design consisting of Analysis, Design, Development, Implementation, and Evaluation. The increasing of students learning motivation before and after using childbirth cube media based on questionnaire. The results of this study showed that the level of validity of this media based on the evaluation of material
\end{abstract}


experts $81,6 \%$ with very valid validity criteria, $72,5 \%$ media experts with valid validity criteria, $89,3 \%$ expert learning implementation plan with very valid validity criteria, Expert Student Worksheet $91,6 \%$ with validity criteria very valid. Student responses to child cube media obtained an average value of $81,1 \%$ with a very good assessment category, the teacher's response to child cube media obtained a value of $100 \%$ with a very good assessment category. Based on the data on student learning motivation before using the media cubes, the average child was 53,61 with the enough category increased to 81,04 with the very high category after using the child cube media.

Keywords: learning media, child cubes, students learning motivation

\section{PENDAHULUAN}

Geometri adalah salah satu bagian dari mata pelajaran matematika. Geometri adalah cabang matematika yang membahas tentang pengukuran. Menurut (Rostika, 2006: 149) geometri bermula dari konsep pangkal yang tidak terdefinisikan secara jelas tetapi diyakini adanya dan dapat diilustrasikan. Geometri tidak hanya mengembangkan kemampuan kognitif siswa tetapi juga membantu dalam pembentukan memori yaitu objek konkret menjadi abstrak. Geometri membahas tentang berbagai masalah yang berkaitan dengan kehidupan sehari-hari (Rostika, 2006: 149).

Geometri pada sekolah dasar harus diajarkan dengan berpusat pada siswa, dengan segala sifat-sifat dan kebutuhannya serta memfokuskan pada lingkungan fisik siswa (Suharjana, 2008: 1). Pembelajaran geometri di sekolah dasar seharusnya dilakukan sesuai dengan kekhasan konsep dan perkembangan berpikir siswa dan berfungsi untuk kehidupan sehari-hari. Pembelajaran geometri sebaiknya diawali dengan hal yang nyata menuju hal yang teoritis, sederhana menuju hal yang saling berhubungan, serta dari hal yang mudah menuju hal yang sulit (Suharjana, 2009: 2). Tetapi pada kenyataanya, hasil belajar siswa pada materi geometri di tingkat sekolah dasar masih tergolong rendah. Berdasarkan hasil observasi yang dilakukan di Sekolah Dasar Negeri Blayu 01 Kecamatan Wajak Kabupaten Malang menunjukkan bahwa banyak siswa yang kurang teliti serta kesulitan dalam mengerjakan soal geometri bangun ruang kubus. Sejalan dengan hasil penelitian (Darwis, Sugita, \& Anggraini, 2015) yang mengungkapkan bahwa siswa masih mengangap materi geometri hal yang sulit dipelajari.

Kenyataan yang terjadi di lapangan, masih banyak guru yang mengajarkan matematika dengan metode ceramah tanpa menggunakan media pembelajaran, dan hanya memberi tugas latihan di lembar kerja siswa. Di samping itu, siswa kurang dilibatkan pada lingkungan belajar yang nyata 
dan guru dalam pembelajaran, dan guru lebih menguasai kegiatan belajar mengajar. (Alfansyur \& Mariyani, 2019) mengungkapkan bahwa guru memaparkan materi pembelajaran masih dominan menggunakan metode ceramah dan berakibat pada rasa bosan, malas, dan kurang termotivasi untuk belajar. Senada dengan hal tersebut (Afandi, 2015) juga berpendapat bahwa media pembelajaran mampu mengatasi kebosanan siswa serta memotivasi siswa untuk mengikuti pembelajaran yang menarik. Sedangkan (Deti, 2008) menyatakan bahwa dalam pembelajaran matematika banyak siswa yang bosan karena pembelajaran kurang menarik, kurang diberi kesempatan untuk aktif merekayasa benda-benda secara langsung, sehingga sebagian siswa sulit menguasai setiap materi yang diajarkan, sehingga motivasi belajar siswa menjadi rendah.

Motivasi belajar yang rendah akan mempengaruhi hasil belajar matematika. Belajar matematika yang penting adalah memberikan pengalaman belajar bagi siswa. Hal ini sejalan dengan teori metode penemuan Burner dalam (Heruman, 2007) yang mengungkapkan bahwa dalam pembelajaran matematika siswa harus menemukan sendiri berbagai pengetahuan yang diperlukannya. Manfaat pengalaman belajar secara langsung adalah memperoleh pengetahuan dengan suatu cara yang dapat melatih berbagai kemampuan belajar siswa, merangsang keingintahuan serta memotivasi kemampuan siswa (Heruman, 2007).

Berdasarkan uraian di atas, perlu dikembangkan media pembelajaran yang mampu memotivasi siswa dalam mempelajari materi yang dianggap sulit yaitu volume bangun ruang kubus. Hal ini karena keterbatasan media pembelajaran yang digunakan. Salah satu media pembelajaran yang dapat digunakan untuk memotivasi belajar siswa dalam materi geometri bangun ruang kubus adalah kubus beranak. Media pembelajaran kubus beranak merupakan salah satu media pembelajaran yang didesain khusus untuk kepentingan pembelajaran matematika. Media ini dirasa cocok digunakan untuk membantu siswa dalam menemukan konsep volume bangun ruang kubus menggunakan kubus satuan.

\section{METODE PENELITIAN}

Penelitian ini menggunakan model ADDIE (Analysis, Design, Development, Implementation, Evaluation) yang dikembangkan oleh Dick and Carry (1996) dalam (Mulyatiningsih, 2012). Prosedur penelitian ini menggunakan model ADDIE yang tahapannya sebagai berikut. 
Dike Rinanda Irfi'ani, Wuli Oktiningrum

Meningkatkan Motivasi Belajar Siswa Melalui Media Kubus Beranak dalam Pembelajaran Matematika

1. Analysis (Analisis)

Studi pendahuluan yang dilakukan dengan cara wawancara pada guru kelas dan observasi selama pembelajaran di kelas. Hasil wawancara kemudian dianalisis.

2. Design (Perancangan)

Tahap perancangan dilakukan dengan menentukan unsur-unsur yang diperlukan dalam mengembangkan media pembelajaran. Hal-hal yang diperlukan adalah rancangan media kubus beranak, perangkat pembelajaran yang akan digunakan untuk uji coba serta kisi-kisi dan lembar validasi dari setiap komponen yang diperlukan dalam pengembangan media kubus beranak.

3. Development (Pengembangan)

Tahap ini, media pembelajaran dikembangkan sesuai dengan rancangan yang telah ditentukan. Setelah media pembelajaran kubus beranak selesai, akan divalidasi oleh ahli materi dan ahli media. Pada tahap validasi, validator menggunakan angket validasi yang kemudian dianalisis menggunakan skala likert dengan interval sebagai berikut.

Tabel 1. Skala Likert

\begin{tabular}{lc}
\hline \multicolumn{1}{c}{ Skala Jawaban } & Nilai \\
\hline Tidak relevan/ tidak baik & 1 \\
\hline Kurang relevan/ kurang baik & 2 \\
\hline Relevan/baik & 3 \\
\hline Sangat relevan/sangat baik & 4 \\
\hline (Sugiono, 2017: 135) &
\end{tabular}

4. Implementation (Implementasi)

Tahap implementasi dilakukan secara terbatas pada siswa yang kelas 5 Sekolah Dasar. Penulis melakukan pembelajaran menggunakan media pembelajaran kubus beranak yang telah dikembangkan. Guru kelas bertugas sebagai observer dan instrumen yang digunakan adalah lembar observasi keterlaksanaan pembelajaran.

5. Evaluation (Evaluasi)

Pada tahap evaluasi, penulis menganalisis hasil respon siswa dan respon guru terhadap media kubus beranak untuk menentukan nilai kelayakan media kubus beranak yang dikembangkan. Motivasi belajar siswa dianalisis untuk mengetahui bagaimana peningkatan motivasi belajar siswa sebelum dan sesudah menggunakan media kubus beranak.

Angket respon dan angket motivasi menggunakan skala likert yang terdiri dari bentuk pernyataan positif dan bentuk pernyataan negatif. Setiap pernyataan terdiri dari kategori pilihan jawaban, yaitu sangat setuju, setuju, 
Dike Rinanda Irfi'ani, Wuli Oktiningrum

Meningkatkan Motivasi Belajar Siswa Melalui Media Kubus Beranak dalam Pembelajaran Matematika

tidak setuju, dan sangat tidak setuju. Setiap kategori jawaban masing-masing memiliki bobot nilai yang akan dijelaskan pada tabel berikut.

Tabel 2 Bobot Nilai Pernyataan Positif

\begin{tabular}{cc}
\hline Kategori & Bobot Nilai \\
\hline SS (Sangat Setuju) & 4 \\
\hline S (Setuju) & 3 \\
\hline TS (Tidak Setuju) & 2 \\
\hline STS (Sangat Tidak Setuju) & 1 \\
\hline
\end{tabular}

Tabel 3 Bobot Nilai Pernyataan Negatif

\begin{tabular}{cc}
\hline Kategori & Bobot Nilai \\
\hline SS (Sangat Setuju) & 1 \\
\hline S (Setuju) & 2 \\
\hline TS (Tidak Setuju) & 3 \\
\hline STS (Sangat Tidak Setuju) & 4 \\
\hline
\end{tabular}

Teknik analisis data dalam penelitian ini adalah sebagai berikut.

1. Penilaian Kelayakan Media

Kriteria penilaian terhadap kelayakan media dari lembar validasi tersaji pada tabel 4 berikut dan dinyatakan dalam persentase yang dihitung dengan menggunakan rumus berikut.

Persentase nilai kelayakan $=\frac{\text { Skor yang diperoleh }}{\text { Skor maksimal }} \times 100 \%$

(Arikunto, 2010: 272).

Tabel 4. Kriteria Kelayakan Secara Deskriptif

\begin{tabular}{ccc}
\hline Kriteria Validitas & Kualifikasi & Tingkat Validitas \\
\hline $76 \%-100 \%$ & Sangat valid & Sudah layak digunakan \\
\hline $51 \%-75 \%$ & Valid & Sudah layak digunakan \\
\hline $26 \%-50 \%$ & Kurang valid & Direvisi \\
\hline $0 \%-25 \%$ & Sangat kurang valid & Direvisi \\
\hline
\end{tabular}

(Arikunto, 2010: 272)

2. Penilaian respon siswa dan guru

Data angket motivasi belajar siswa, respon siswa dan guru diperoleh dari hasil pengisian lembar angket. Untuk menganalisis data yang diperoleh dari penyebaran angket, rumus distribusi frekuensi yang digunakan sebagai berikut.

$$
\mathrm{P}=\frac{f}{N} \times 100 \%
$$


Dike Rinanda Irfi'ani, Wuli Oktiningrum

Meningkatkan Motivasi Belajar Siswa Melalui Media Kubus Beranak dalam Pembelajaran Matematika

dengan $\mathrm{P}=$ angka presentase, $\mathrm{N}=$ skor keseluruhan dan $f=$ skor yang diperoleh (Arikunto, 2006: 12).

Tabel 5. Kategori Kriteria Penilaian

\begin{tabular}{cc}
\hline Nilai \% & Kategori Penilaian \\
\hline $80-100$ & Baik Sekali \\
\hline $66-79$ & Baik \\
\hline $56-65$ & Cukup \\
\hline $40-55$ & Kurang \\
\hline $30-39$ & Gagal \\
\hline
\end{tabular}

(Arikunto, 2006: 245)

3. Penilaian angket motivasi belajar siswa

Motivasi belajar siswa diukur menggunakan angket motivasi. Angket motivasi belajar siswa dihitung dengan menjumlahkan skor yang diperoleh siswa. Skor yang diperoleh kemudian dikategorikan sesuai tabel berikut.

Tabel 6. Pedoman Kriteria Penilaian Motivasi Belajar

\begin{tabular}{cc}
\hline Interval & Kategori \\
\hline $81-100$ & Sangat tinggi \\
\hline $61-80$ & Tinggi \\
\hline $41-60$ & Cukup \\
\hline $21-40$ & Kurang \\
\hline $0-20$ & Kurang sekali \\
\hline
\end{tabular}

(Saputra, 2018)

\section{HASIL DAN PEMBAHASAN}

Data kuantitatif diperoleh dari angket penilaian, sedangkan data kualitatif diperoleh dari saran atau penilaian tambahan dari validator.

1. Hasil validasi produk

a. Hasil validasi ahli materi

Hasil validasi ahli materi dapat dilihat pada tabel 7 berikut.

Tabel 7. Hasil Penilaian Ahli Materi terhadap Media Kubus Beranak

\begin{tabular}{cccccc}
\hline Pernyataan & Skor & $\begin{array}{c}\text { Skor } \\
\text { Maksimal }\end{array}$ & $\begin{array}{c}\mathbf{P} \\
\mathbf{( \% )}\end{array}$ & $\begin{array}{c}\text { Kriteria } \\
\text { Kevalidan }\end{array}$ & Keterangan \\
\hline Jumlah & 49 & 60 & 81,6 & Sangat valid & Tidak revisi \\
\hline
\end{tabular}


Dike Rinanda Irfi'ani, Wuli Oktiningrum

Meningkatkan Motivasi Belajar Siswa Melalui Media Kubus Beranak dalam Pembelajaran Matematika

Berdasarkan tabel 7 diketahui bahwa hasil validasi ahli materi dengan tingkat kevalidan sangat valid, keterangan tidak revisi, dan perolehan presentase 81,6.

b. Hasil validasi ahli media

Hasil validasi ahli media dapat dilihat pada tabel 8 berikut.

Tabel 8. Hasil Penilaian Ahli Media terhadap Media Kubus Beranak

\begin{tabular}{lccccc}
\hline \multicolumn{1}{c}{ Pernyataan } & Skor & $\begin{array}{c}\text { Skor } \\
\text { Maksimal }\end{array}$ & P (\%) & $\begin{array}{c}\text { Kriteria } \\
\text { Kevalidan }\end{array}$ & Keterangan \\
\hline Jumlah & 29 & 40 & 72,5 & Valid & Tidak revisi \\
\hline
\end{tabular}

Berdasarkan tabel 8 diketahui bahwa hasil validasi ahli meida dengan tingkat kevalidan valid, keterangan tidak revisi, dan perolehan presentase 72,5.

c. Hasil validasi rencana pelaksanaan pembelajaran

Hasil validasi rencana pelaksanaan pembelajaran dapat dilihat pada tabel 9 berikut.

Tabel 9. Hasil Penilaian Rencana Pelaksanaan Pembelajaran

\begin{tabular}{lccccc}
\hline Pernyataan & Skor & $\begin{array}{c}\text { Skor } \\
\text { Maksimal }\end{array}$ & P (\%) & $\begin{array}{c}\text { Kriteria } \\
\text { Kevalidan }\end{array}$ & Keterangan \\
\hline Jumlah & 50 & 56 & 89,3 & Sangat Valid & Tidak revisi \\
\hline
\end{tabular}

Berdasarkan tabel 9 diketahui bahwa hasil validasi ahli rencana pelaksanaan pembelajaran dengan tingkat kevalidan sangat valid, keterangan tidak revisi, dan perolehan presentase 89,3.

d. Hasil validasi lembar kerja siswa

Hasil validasi lembar kerja siswa dapat dilihat pada tabel 10 berikut.

Tabel 10. Hasil Penilaian Lembar Kerja Siswa

\begin{tabular}{lccccc}
\hline Pernyataan & Skor & Skor Maks & P (\%) & $\begin{array}{c}\text { Kriteria } \\
\text { Kevalidan }\end{array}$ & Keterangan \\
\hline Jumlah & 33 & 36 & 91,6 & Sangat Valid & Tidak revisi \\
\hline
\end{tabular}

Berdasarkan tabel 10 diketahui bahwa hasil validasi ahli lembar kerja siswa dengan tingkat kevalidan sangat valid, keterangan tidak revisi, dan perolehan presentase 91,6.

2. Hasil uji coba produk

Data yang diperoleh dari hasil uji coba produk media kubus beranak terdiri dari respon siswa terhadap media kubus beranak, respon guru 
Dike Rinanda Irfi'ani, Wuli Oktiningrum

Meningkatkan Motivasi Belajar Siswa Melalui Media Kubus Beranak dalam Pembelajaran Matematika

terhadap kubus beranak, dan motivasi belajar siswa. Data kuantitatif yang didapatkan penulis melalui pemberian angket.

a. Respon siswa

Respon siswa terhadap media kubus dapat dilihat pada Tabel 11 berikut.

Tabel 11. Hasil Penilaian Respon Siswa terhadap Media Kubus Beranak

\begin{tabular}{lcccc}
\hline Pernyataan & Skor & $\begin{array}{c}\text { Skor } \\
\text { Maksimal }\end{array}$ & P (\%) & Kategori Penilaian \\
\hline Jumlah & 146 & 180 & 81,1 & Baik Sekali \\
\hline
\end{tabular}

Berdasarkan Tabel 11 diketahui bahwa respon siswa dengan kategori penilaian baik sekali dan memperoleh presentase penilaian 81,1 .

b. Respon guru

Respon guru terhadap media kubus beranak merupakan data yang digunakan untuk mengetahui kelayakan media kubus beranak setelah siswa menggunakan media kubus beranak. Paparan hasil respon guru dapat dilihat pada tabel 12 berikut.

Tabel 12. Hasil Penilaian Respon Guru terhadap Media Kubus Beranak

\begin{tabular}{ccccc}
\hline Pernyataan & Skor & Skor Maksimal & P (\%) & Kategori Penilaian \\
\hline Jumlah & 8 & 8 & 100 & Baik Sekali \\
\hline
\end{tabular}

c. Motivasi belajar siswa

Hasil rekapitulasi motivasi belajar siswa sebelum dan sesudah menggunakan media kubus beranak dapat dilihat pada tabel 13 berikut.

Tabel 13. Hasil Motivasi Belajar Siswa

\begin{tabular}{ccccc}
\hline \multirow{2}{*}{ Nama Responden } & \multicolumn{4}{c}{ Hasil Motivasi } \\
\cline { 2 - 5 } & Sebelum & Kategori & Sesudah & Kategori \\
\hline Rata-rata & 53.611111 & Cukup & 81.041667 & Sangat Tinggi \\
\hline
\end{tabular}

Produk yang dihasilkan dalam penelitian ini adalah media kubus beranak. Media pembelajaran kubus beranak setelah dikembangkan dan divalidasi oleh para ahli dan dinyatakan valid layak untuk diujicobakan pada siswa kemudian diujicobakan secara terbatas pada 12 peserta didik. Media kubus beranak digunakan untuk media pembelajaran kelas 5 pada mata pelajaran matematika materi volume bangun ruang kubus. Menurut (Heruman, 2007) pembelajaran matematika hendaknya terjadi penemuan 
kembali konsep pengetahuan walaupun secara sederhana. Tujuannya adalah menumbuhkan keingintahuan siswa, serta memotivasi kemampuan siswa. Media pembelajaran yang konkret dapat membantu siswa menemukan konsep yang hendak dicapai. Media kubus beranak digunakan untuk media penemuan kembali konsep yang sudah ada tentang volume kubus dengan media yang konkret yang bisa dipegang secara langsung oleh siswa.

Tahap uji coba terbatas dilakukan di lingkungan penulis dengan 12 siswa sebagai subjek uji coba. Sebelum memulai pembelajaran, penulis menyebarkan angket motivasi belajar untuk mengetahui tingkat motivasi belajar siswa sebelum menggunakan media kubus beranak. Hasil motivasi belajar siswa sebelum menggunakan media kubus beranak, rata-rata 53,61 dengan kategori penilaian motivasi belajar cukup. Setelah pengisian angket motivasi belajar selesai penulis memulai pembelajaran menggunakan media kubus beranak sesuai dengan tahapan pembelajaran yang telah disusun dalam rencana pelaksanaan pembelajaran.

Pembelajaran menggunakan kubus beranak dilakukan dengan cara membagi siswa ke dalam beberapa kelompok. Setelah dibagi, setiap kelompok menentukan ketua kelompok yang akan bertanggung jawab pada kelompoknya. Setiap kelompok mendapatkan satu paket media kubus beranak yang telah disediakan. Siswa diarahkan membaca petunjuk yang ada pada bagian depan kemasan kubus beranak. Setelah membuka dan mengeluarkan seluruh komponen kubus beranak meliputi: 1 kubus raksasa, 1 balok raksasa, beberapa kubus mini, lembar kerja siswa, dan buku petunjuk yang ada di dalamnya. Siswa diarahkan mengerjakan lembar kerja siswa. Siswa bersama kelompoknya menyelesaikan permasalahan dengan bantuan media kubus beranak.

Guru berkeliling membantu kelompok yang terlihat kebingungan. Kelompok A terlihat sangat antusias dalam membaca lembar kerja siswa kemudian mengerjakan sesuai dengan petunjuk, sehingga penulis merasa tidak perlu membantu kelompok A. kelompok B dan C terlihat bingung bagaimana pengguanaan media kubus beranak. Kelompok $\mathrm{C}$ dengan cepat memahami petunjuk penggunaan media kubus beranak setelah penulis membaca ulang dengan keras petunjuk penggunaan kubus beranak. Sedangkan kelompok B baru paham langkah-langkah pada petunjuk setelah penulis menjelaskan kembali dengan bahasa yang lebih sederhana, bahwa media kubus beranak terdiri dari beberapa komponen untuk bisa memanfaatkan media kubus beranak diperlukan pemahaman pada buku petunjuk agar bisa menyelesaikan lembar kerja siswa. Setelah semua kelompok paham maka mereka berlomba untuk menyelesaikan lembar kerja siswa bersama kelompoknya. 
Setelah selesai menyelesaikan setiap tahap pada lembar kerja siswa, siswa mengangkat media kubus beranak. Kelompok yang paling cepat selesai diberikan kesempatan mempresentasikan hasil diskusi lembar kerja siswa bersama kelompoknya di depan kelas. Setelah setiap kelompok selesai mempresentasikan hasil diskusinya bersama-sama, siswa diajak membuat kesimpulan tentang media kubus beranak yang digunakan untuk menemukan konsep volume kubus, bahwa volume merupakan isi dari bangun ruang, dan untuk mencari volume suatu bangun ruang dapat menghitung jumlah seluruh kubus satuan yang memenuhi kubus raksasa. Agar lebih mudah menghitung banyaknya kubus mini dalam satu kubus raksasa, dapat dicari dengan menghitung banyaknya kubus satuan yang memenuhi bagian dasar kubus raksasa dikalikan dengan banyaknya tumpukan, kemudian dimasukkan ke dalam bahasa matematika bahwa volume merupakan hasil kali antara luas alas dengan tinggi. Setelah penjelasan tersebut maka siswa mengerjakan soal latihan untuk mengetahui tingkat pemahaman terhadap materi.

Setelah semua selesai mengerjakan soal siswa diminta menukarkan hasil kerjanya untuk dibahas bersama yang kemudian dinilai oleh guru. Siswa terlihat sangat senang karena mereka merasa bisa mengerjakan soal dengan mudah dan hasilnya bagus. Pembelajaran diakhiri dengan tanya jawab tentang pembelajaran yang telah dilakukan apakah pembelajaran hari ini menyenangkan dan apa saja kesulitan yang dihadapi oleh siswa selama pembelajaran berlangsung, memberi kesempatan bertanya pada siswa tentang hal yang kurang dimengerti, serta pembelajaran ditutup dengan doa dan salam.

Setelah pembelajaran selesai, penulis menyebarkan angket motivasi belajar yang kedua dan angket respon siswa terhadap media kubus beranak yang digunakan selama pembelajaran. Hasil motivasi belajar siswa setelah menggunakan media kubus beranak rata-rata 81,04 dengan kategori sangat tinggi. 6 siswa dengan kategori sangat tinggi dan 6 siswa dengan kategori tinggi. Berdasarkan analisis data, motivasi belajar siswa meningkat sesudah menggunakan media kubus beranak. Sehingga dapat dikatakan bahwa media kubus beranak dapat meningkatkan motivasi belajar siswa.

Menurut Hamalik (1994) dalam (Retnowati, 2017) untuk meningkatkan motivasi belajar, sikap, dan cara belajar yang lebih efektif, serta menumbuhkan pola pikir yang lebih tinggi dapat ditingkatkan melalui penggunaan media pembelajaran. Guru yang menggunakan media pembelajaran secara baik dalam proses pembelajaran akan memotivasi siswa dalam menerima materi dan meningkatkan semangat belajar siswa dalam menerima materi baru dengan mudah. Senada dengan pendapat tersebut, (Nurohmah, 2015) mengungkapkan bahwa peranan penting media 
pembelajaran adalah untuk meningkatkan motivasi belajar siswa. Hal ini dibuktikan dengan semakin termotivasinya siswa dalam proses belajar mengajar, siswa merasa pembelajaran lebih menarik.

Hasil uji coba yang telah dilakukan menunjukkan motivasi belajar siswa meningkat setelah diterapkan media pembelajaran kubus beranak. Hal ini dibuktikan dengan adanya perubahan motivasi belajar siswa sebelum menggunakan media kubus beranak rata-rata 53,6 dengan kategori penilaian motivasi belajar cukup. Setelah melakukan perlakuan yaitu dengan melakukan pembelajaran menggunakan media kubus beranak, nilai rata-rata motivasi belajar siswa menjadi 81,04 dengan kategori sangat tinggi. Hal ini menunjukkan bahwa media kubus beranak berpengaruh terhadap motivasi belajar siswa. Motivasi belajar siswa meningkat setelah menggunakan media kubus beranak.

\section{KESIMPULAN DAN SARAN}

Berdasarkan hasil penelitian dan pembahasan yang telah dilakukan, penulis menarik kesimpulan dari penelitian ini adalah media pembelajaran kubus beranak dalam pelajaran matematika materi volume bangun ruang kubus kelas 5 Sekolah Dasar yang telah dikembangkan dan dinilai oleh validasi ahli materi dengan rata-rata penilaian $81,6 \%$ dikategorikan sangat valid, validasi ahli media dengan rata-rata penilaian $72,5 \%$ dikategorikan valid, validasi RPP dengan rata-rata penilaian $89,3 \%$ dikategorikan sangat valid, validasi lembar kerja siswa 91,6\% dikategorikan sangat valid. Uji respon siswa dengan rata-rata $81,1 \%$ dikategorikan baik sekali, serta uji respon guru $100 \%$ dikategorikan baik sekali. Hal ini menunjukkan media kubus beranak yang telah dikembangkan valid dan layak untuk digunakan sebagai media pembelajaran pada materi volume bangun ruang kubus kelas 5 Sekolah Dasar.

Media kubus beranak pada materi volume bangun ruang kubus kelas 5 Sekolah Dasar yang telah dikembangkan dan di ujicobakan pada 12 siswa digunakan untuk membandingkan motivasi belajar siswa sebelum dan sesudah menggunakan media kubus beranak. Hasil motivasi belajar siswa sebelum menggunakan media kubus beranak 53,61 dikategorikan cukup dan setelah menggunakan media kubus beranak 81,04 dikategorikan sangat tinggi sehingga dapat disimpulkan rata-rata motivasi belajar siswa meningkat sebesar 27,43. Sehingga dapat disimpulkan bahwa media kubus beranak dapat meningkatkan motivasi belajar siswa kelas 5 Sekolah Dasar. 
Dike Rinanda Irfi'ani, Wuli Oktiningrum

Meningkatkan Motivasi Belajar Siswa Melalui Media Kubus Beranak dalam Pembelajaran Matematika

Berdasarkan hasil penelitian dan pengembangan media pembelajaran kubus beranak pada materi volume bangun ruang sederhana kubus kelas 5 Sekolah Dasar, dapat diberikan saran berikut. Saran untuk pengembangan lebih lanjut yaitu pengembangan media pembelajaran kubus beranak dapat dikembangkan berkelanjutan dengan warna dan ukuran yang berbeda dan teknik permainan kubus beranak dapat dikembangkan lebih menarik serta menantang.

\section{UCAPAN TERIMA KASIH}

Terima kasih penulis ucapkan kepada ibu Wuli Oktiningrum, M.Pd yang dengan kegigihannya membimbing penulis, ibu Harini yang selama ini membiayai penulis dalam menempuh pendidikan, ibu Iin Puji Astuti, S,Psi yang menjadi observer penelitian, validator penelitian bapak Muhammad Islahul Mukmin, M.Si, ,M.Pd, Ibu Nanik Ulfa, M.Pd.

\section{DAFTAR RUJUKAN}

Afandi, R. (2015). Pengembangan Media Pembelajaran Permainan Ular Tangga Untuk Meningkatkan Motivasi Belajar Siswa dan Hasil Belajar IPS di Sekolah Dasar. JINoP (Jurnal Inovasi Pembelajaran), 1(1), 77-89. https://doi.org/10.22219/jinop.v1i1.2450

Alfansyur, A., \& Mariyani, M. (2019). Pemanfaatan Media Berbasis ICT “KAHOOT” Dalam Pembelajaran PPKn untuk Meningkatkan Motivasi Belajar Siswa. Bhineka Tunggal Ika: Kajian Teori Dan Praktik Pendidikan PKn, 6(2). https://doi.org/10.36706/jbti.v6i2.10118

Arikunto, S. (2006). Dasar-Dasar Evaluasi Pendidikan. Jakarta: Bumi Aksara.

Arikunto, S. (2010). Dasar-Dasar Evaluasi Pendidikan Edisi 2. Jakarta: Bumi Aksara.

Darwis, Sugita, G., \& Anggraini. (2015). Peningkatan Pemahaman Siswa pada Materi Volume Kubus dan Balok Menggunakan Alat Peraga di Kelas V SDN Pebatae Kecamatan Bumi Raya Kabupaten Morowali. Jurnal Kreatif Tadulako Online, 1(1), 228-337.

Deti, R. (2008). Pembelajaran Volume Bangun Ruang Melalui Pendekatan Konstruktivisme untuk Siswa Sekolah Dasar. Jurnal Pendidikan Dasar, (9).

Heruman. (2007). Model Pembelajaran Matematika di Sekolah Dasar. Bandung: PT Remaja Rosydakarya.

Mulyatiningsih, E. (2012). Pengembangan Model Pembelajaran. Retrieved from

http://staffnew.uny.ac.id/upload/131808329/pengabdian/7cpengem bangan-model-pembelajaran.pdf 
Dike Rinanda Irfi'ani, Wuli Oktiningrum

Meningkatkan Motivasi Belajar Siswa Melalui Media Kubus Beranak dalam Pembelajaran Matematika

Nurohmah, Y. A. (2015). Peranan Media Pembelajaran dalam meningkatkan motivasi belajar siswa pada mata pelajaran Tarikh kelas VIII di SMP Muhammadiyah 5 Surakarta Tahun Pelajaran 2014/2015. Universitas Muhammadiyah Surakarta. Retrieved from http://eprints.ums.ac.id/34572/

Retnowati. (2017). Pengaruh Penggunaan Media Pembelajaran terhadap Motivasi Belajar Siswa pada Mata Pelajaran Pendidikan Agama Islam di SMP Negeri 1 Punggur Kabupaten Lampung Tengah. Institut Agama Islam Negeri Metro. Retrieved from http://repository.metrouniv.ac.id/id/eprint/1808/1/Skripsi Retnowati.pdf

Rostika, N. A. (2006). Konsep Dasar Matematika. Bandung: UPI Press.

Saputra, J. A. (2018). Peningkatan Motivasi Belajar melalui Penerapan Media Gambar pada Mata Pelajaran IPS Kelas IX di MTs Putra Islahuddin Kediri Tahun Pelajaran 2017/2018. Universitas Islam Negeri Mataram. Retrieved from http://etheses.uinmataram.ac.id/771/1/Edi Januar Saputra151136046.pdf

Suharjana, A. (2008). Pengenalan Bangun Ruang dan Sifat-sifatnya di SD. Yogyakarta: Pusat Pengembangan dan Pemberdayaan Pendidik dan Tenaga Kependidikan Matematika.

Suharjana, A. (2009). Geometri Datar dan Ruang di SD. Sleman: PPPTK Matematika Yogyakarta. 